\title{
Delineation of Physicochemical \\ Properties for Anacardium occidentale, Artocarpus heterophyllus \& Syzygium cumini Seed oils
}

\author{
*K.M.V Ravi Teja ${ }^{1}$, Dr.P.Issac Prasad ${ }^{2}$, Dr.K.Vijaya Kumar Reddy ${ }^{3}$ \\ ${ }^{* 1}$ Research scholar, K L E F, Department of Mechanical Engineering, Guntur, Andhra Pradesh, India \\ ${ }^{2}$ Professor, K L E F, Department of Mechanical Engineering, Guntur, Andhra Pradesh, India, \\ ${ }^{3}$ Professor \& Director of R \& D, F.I.E, ISTE, MCI, ASME, Mechanical Engineering, JNTUH, Telangana ,India.
}

\begin{abstract}
A series of experiments on bio-oil and property measurements were performed, analyzed and compared in search of an alternative solution to the rising demand of fossil fuel and its depleting supply around the globe are attempted. Anacardium occidentale, Artocarpus heterophyllus and Syzygium cumini seed oils used in the preparation of bio oil were examined. These seed oils are high in conjugated fatty acids. Anacardium occidentale, Artocarpus heterophyllus and Syzygium cumini seed oils are Sustainable and biodegradable biofuels with similar properties to petro-diesel fuel. The biochemical and biophysical properties comparative analysis of the selected oils with petrol is presented. Specific fuel properties, such as $\mathrm{pH}$, flash point, fire point, redwood viscosity, calorific strength, carbon residue, cloud level, pour point, boiling point, aliphatic / aromatic compounds and hydrocarbons content for the selected oils are reported.
\end{abstract}

Key words : Bio-oils,S1-Anacardium occidentale seed oil, S2-Artocarpus heterophyllus seed oil and S3-Syzygium cumini seed oil, Physiochemical properties

\section{INTRODUCTION}

As years go by, the use of fossil-derived fuels is rising tremendously and the market to support the use is gradually declining. And it is very clear that the supply of these fossil fuels will vanish within the next ten to twenty years. Science gave birth to something called Alternative Fuel, to fulfil the need for fuel use. Alternative fuels are non-fossil fuel-derived fuels, which are often derived from renewable sources. Alternative fuels consist primarily of Bio-waste-derived ethanol and biodiesel. Biofuels are considered the most promising alternative fueling source. The main reason for approaching the physicochemical properties of an bio-oil is to know the characteristic like boiling point, Calorific value, acidity etc and these characteristics will vary depending on the its composition. Vegetable oils are preferred as alternatives for fossil fuels and have been used for many years. Rudolph Diesel first utilized peanut oil in the compression engine (Shay, 1993). In the current scenario the massive rise in vehicle use often greatly raises the very high demand for the fuel price. Using the alternative fuel will fulfill the demand[2]. Some of the advantages of using these bio oils are lower harmful exhaust emissions, biodegradability, non-toxicity. Bio oils are environmentally friendly, and are also sustainable from agricultural sources. Biodiesel fuel properties depend to a large extent on feed stocks, which vary not only with the species but also with the place of production [1]. In India we can mainly see the production and usage of oil seed like groundnut, coconut, sunflower, rapeseed, mustard, karanja, Jatropha, Neem, rubber seed, cotton seed, rice bran and tropical fruits such as, Syzygium cumini, Artocarpus heterophyllus and Anacardium occidentale a potentially important indigenous and commercial fruits. These fruits having high amount of vitamins, tannin and anthocyanins. All of these fruit holds with high significant values. There are various factors to be considered for the production of any form of bio oil that are $\mathrm{pH}$ value, flash point, fire point, Redwood viscosity, calorific value, carbon residue, cloud point, pour point, boiling point, hydrocarbons. Biodiesel is defined as methyl fatty acid or ethyl esters made from vegetable oils or animal fats as an alternative diesel fuel. It is removable, biodegradable and non-renewable [5, 6]. In this present research, Anacardium occidentale, Syzygium cumini and Artocarpus heterophyllus seed oil are used to produce biodiesel.

\section{OIL EXTRACTION}

At $35^{\circ} \mathrm{C}$ for five days, $2 \mathrm{~kg}$ of the seeds were harvested and dried in the sun to minimize the moisture content to around 7\%[7] and manually trimmed to remove the shell. The seeds, which averaged $5 \mathrm{~mm}$ in diameter, were milled to reduce diameter to approximately $1.16 \mathrm{~mm}$ and reveal more area for higher oil extraction $[8,9]$. The oil was extracted with n-hexane as the solvent in a soxhlet extractor. The oil was leached at $60^{\circ} \mathrm{C}$ for 8 hours and the hexane in the 
mixture was removed using a $75^{\circ} \mathrm{C}$ operated rotary vacuum evaporator. The oil obtained was weighed, and equation 1 determined the percentage oil yield [10].

$$
\% \text { Oil yield }=\frac{\text { Weight of oil extracted }}{\text { Total weight of cashew nuts used }} \times 100
$$

\subsection{Codes for Oils}

\begin{tabular}{|c|c|c|}
\hline S.No & Code & Oils \\
\hline 1 & S1 & Anacardium occidentale seed oil \\
\hline 2 & S2 & Artocarpus heterophyllus seed oil \\
\hline 3 & S3 & Syzygium cumini seed \\
\hline 4 & S4 & Diesel \\
\hline
\end{tabular}

Table-1 Codes for Oils

\section{DETERMINATION OF FUEL AND PHYSIOCHEMICAL PROPERTIES}

The fuel and physiochemical properties of the $\mathrm{S}$, $\mathrm{S} 2$ and $\mathrm{S} 3$ bio oils are unblended. These were determined and Testings were undertaken in Koneru Lakshmaiah Education Foundation, chemistry, Bio Technology, Petroleum Civil laboratories, and laboratory of thermal in Narsaraopeta Engineering College.

\section{$3.1 \mathrm{pH}$ Value:}

The $\mathrm{pH}$ value is measured using a $\mathrm{pH}$ metre to determine hydrogen ion activity (acidity or alkalinity) in solution. The measurements vary from 0 to 14 . The $\mathrm{pH}$ of 7 is neutral, the acid is $<7$ and the base is $>7$.

\subsection{Flash and Fire Point:}

According to ASTM D6751 by using Kehler Model K-16270 (Pensky-Martens Closed Flash Tester) Flash and fire points are measured.

\subsection{Kinematic viscosity:}

It involves measurement of time for a fixed amount of the fuel which is allowed to flow under gravity through a capillary at temperature different ranges $\left(50,60,70,80^{\circ} \mathrm{C}\right)$ and the equipment used for determining the kinematic viscosity is Herzog GmbH MP-480

\subsection{Calorific value:}

Calorific value was measured by Bomb calorimeter. A chamber filled with pure oxygen and burn it, measuring the amount of heat (i.e. energy) that is generated.

Heat lost by Fuel $=$ Heat gained by Water

$$
\mathrm{M}_{\text {fue: }} * \mathrm{CV}=\mathrm{M}_{\mathrm{water}} * \mathrm{C}_{p}\left(\mathrm{~T}_{2}-\mathrm{T}_{1}\right)
$$

\subsection{Carbon Residue:}

Carbon residue is measured using normal protocol involving heating of a fuel sample. The H-2495, Conradson Carbon Residue Apparatus is used to check carbon residue and assess the amount of carbon residue left after an oil has been evaporated and pyrolysed, and to show relative propensities to form coke.

\subsection{Cloud and Pour Point:}

Cloud point is the temperature under which wax in oil creates a cloudy appearance. Minimum temperature at which an oil is semi solid and almost loses its flow properties is pour point.

\subsection{Boiling point:}

Temperature at which liquid vapour pressure equals air and air surrounding pressure transforms into vapour. These oils are more owing due to the increased number of carbon atoms present in the chain. Temperatures at 1 atmosphere where the minimum vapour pressure.

\subsection{Aliphatic/Aromatic:}

Substance burns with a Smoky flame is considered as Aromatic compound, substance burns with non-smoky flame is considered as Aliphatic compound.

\subsection{Pirate test of Hydrocarbons:}

The volume, concentration, temperature, and pressure of the hydrocarbon vapors emitted through a preselected vent. A Picrate is a salt or an ester of picric acid compound which picric acid forms with many aromatic hydrocarbons, aromatic amines, aliphatic amines, alkalines, and other compounds.

\subsection{Aluminum chloride test of Hydrocarbons:}

Process of polymerization and disproportionation which produces fully aromatic and partially aliphatic molecules which presence of Anthracene.

\subsection{UV spectroscopy:}

UV Spectroscopy is used to conduct measurements in UV Spectrometer. Absorbance spectra can recorded and also individual wavelength measurements can conduct, Spectral range of this meter is 200 to $830 \mathrm{~nm}$.

\begin{tabular}{|c|c|c|c|c|c|}
\hline S. No & Property & S1 & S2 & S3 & S4 \\
\hline 1 & $\mathrm{pH}$ Value & 7.4 & 4.9 & 8.2 & $5.5-8$ \\
\hline 2 & $\begin{array}{l}\text { Flash } \\
\text { Point }\end{array}$ & $50^{\circ} \mathrm{C}$ & $90^{\circ} \mathrm{C}$ & $81^{\circ} \mathrm{C}$ & $\begin{array}{c}52- \\
96^{\circ} \mathrm{C}\end{array}$ \\
\hline 3 & Fire Point & $52^{\circ} \mathrm{C}$ & $92^{\circ} \mathrm{C}$ & $85^{\circ} \mathrm{C}$ & $\begin{array}{c}52- \\
96^{\circ} \mathrm{C}\end{array}$ \\
\hline 4 & $\begin{array}{l}\text { Redwood } \\
\text { Viscosity }\end{array}$ & $\begin{array}{c}0.018 \\
\mathrm{~cm}^{2} / \mathrm{se} \\
\mathrm{c}\end{array}$ & $\begin{array}{l}0.0223 \\
\mathrm{~cm}^{2} / \mathrm{sec}\end{array}$ & $\begin{array}{c}0.0166 \\
7 \\
\mathrm{~cm}^{2} / \mathrm{sec}\end{array}$ & $\begin{array}{l}0.820 \\
- \\
0.845 \\
\mathrm{c} \\
\mathrm{m}^{2} / \mathrm{se} \\
\mathrm{c}\end{array}$ \\
\hline 5 & $\begin{array}{l}\text { Calorific } \\
\text { Value }\end{array}$ & $\begin{array}{l}32,231 \\
.11 \mathrm{~J} / \mathrm{g} \\
\end{array}$ & $\begin{array}{c}34,533 . \\
33 \mathrm{~J} / \mathrm{g}\end{array}$ & $\begin{array}{r}17,266 . \\
66 \mathrm{~J} / \mathrm{g}\end{array}$ & $\begin{array}{c}45,00 \\
0 \mathrm{~J} / \mathrm{g}\end{array}$ \\
\hline
\end{tabular}

\section{EXPERIMENTAL RESULTS}


K.M.V Ravi Teja et al., International Journal of Emerging Trends in Engineering Research, 8(10), October 2020, 7062 - 7068

\begin{tabular}{|c|c|c|c|c|c|}
\hline 6 & $\begin{array}{l}\text { Carbon } \\
\text { Residue }\end{array}$ & $\begin{array}{c}16.86 \\
\%\end{array}$ & $5.05 \%$ & $9.49 \%$ & $10 \%$ \\
\hline 7 & $\begin{array}{l}\text { Cloud } \\
\text { Point } \\
\end{array}$ & $7^{\circ} \mathrm{C}$ & $4^{\circ} \mathrm{C}$ & $8^{\circ} \mathrm{C}$ & $4^{\circ} \mathrm{C}$ \\
\hline 8 & $\begin{array}{l}\text { Pour } \\
\text { Point }\end{array}$ & $-9.5^{\circ} \mathrm{C}$ & $-8^{\circ} \mathrm{C}$ & $-4^{\circ} \mathrm{C}$ & $-7^{\circ} \mathrm{C}$ \\
\hline 9 & $\begin{array}{l}\text { Boiling } \\
\text { Point }\end{array}$ & $128^{\circ} \mathrm{C}$ & $135^{\circ} \mathrm{C}$ & $90^{\circ} \mathrm{C}$ & $\begin{array}{l}180-3 \\
60{ }^{\circ} \mathrm{C}\end{array}$ \\
\hline 10 & $\begin{array}{l}\text { Flame } \\
\text { test }\end{array}$ & $\begin{array}{c}\text { Substa } \\
\text { nce } \\
\text { burns } \\
\text { with } \\
\text { smoky } \\
\text { flame } \\
\text { so, } \\
\text { Aroma } \\
\text { tic } \\
\text { Compo } \\
\text { und }\end{array}$ & $\begin{array}{c}\text { Substa } \\
\text { nce } \\
\text { burns } \\
\text { with } \\
\text { smoky } \\
\text { flame } \\
\text { so, } \\
\text { Aromat } \\
\text { ic } \\
\text { Compo } \\
\text { und }\end{array}$ & $\begin{array}{c}\text { Substa } \\
\text { nce } \\
\text { burns } \\
\text { with } \\
\text { smoky } \\
\text { flame } \\
\text { so, } \\
\text { Aromat } \\
\text { ic } \\
\text { Compo } \\
\text { und }\end{array}$ & $\begin{array}{l}\text { Arom } \\
\text { atic }\end{array}$ \\
\hline \multirow[t]{2}{*}{11} & $\begin{array}{l}\text { Hydrocar } \\
\text { bons } \\
\text { Picrate } \\
\text { Test }\end{array}$ & $\begin{array}{l}\text { Observ } \\
\text { ed Red } \\
\text { Color } \\
\text { so, } \\
\text { Presen } \\
\text { ce of } \\
\text { Anthra } \\
\text { cene }\end{array}$ & $\begin{array}{l}\text { Observ } \\
\text { ed Red } \\
\text { Color } \\
\text { so, } \\
\text { Presenc } \\
\text { e of } \\
\text { Anthra } \\
\text { cene }\end{array}$ & $\begin{array}{l}\text { Observ } \\
\text { ed Red } \\
\text { Color } \\
\text { so, } \\
\text { Presenc } \\
\text { e of } \\
\text { Anthra } \\
\text { cene }\end{array}$ & $\begin{array}{l}\text { Obser } \\
\text { ved } \\
\text { Red } \\
\text { Color } \\
\text { so, } \\
\text { Prese } \\
\text { nce of } \\
\text { Anthr } \\
\text { acene }\end{array}$ \\
\hline & $\begin{array}{l}\text { Aluminu } \\
\mathrm{m} \\
\text { Chloride }\end{array}$ & $\begin{array}{c}\text { Observ } \\
\text { ed } \\
\text { Colorle } \\
\text { ss so, } \\
\text { presen } \\
\text { ce of } \\
\text { Anthra } \\
\text { cene }\end{array}$ & $\begin{array}{c}\text { Observ } \\
\text { ed } \\
\text { Colorle } \\
\text { ss so, } \\
\text { presenc } \\
\text { e of } \\
\text { Anthra } \\
\text { cene }\end{array}$ & $\begin{array}{c}\text { Observ } \\
\text { ed } \\
\text { Colorle } \\
\text { ss so, } \\
\text { presenc } \\
\text { e of } \\
\text { Anthra } \\
\text { cene }\end{array}$ & $\begin{array}{c}\text { Obser } \\
\text { ved } \\
\text { Colorl } \\
\text { ess so, } \\
\text { prese } \\
\text { nce of } \\
\text { Anthr } \\
\text { acene }\end{array}$ \\
\hline 12 & $\begin{array}{c}\text { UV } \\
\text { spectrosc } \\
\text { opy }\end{array}$ & $\begin{array}{c}\lambda= \\
599, \\
\text { Abs }= \\
0.0122\end{array}$ & $\begin{array}{c}\lambda= \\
596, \\
\text { Abs }= \\
0.035\end{array}$ & $\begin{array}{c}\lambda= \\
600, \\
\text { Abs }= \\
0.268\end{array}$ & $\begin{array}{c}\lambda= \\
750, \\
\text { Abs } \\
=0.82\end{array}$ \\
\hline
\end{tabular}

Table-2:Experimental results

\section{RESULTS AND DISCUSSION}

The oil yield is unblended Bio-oil. Physicochemical properties of biooils and results are obtained and calculated the properties of $\mathrm{pH}$ value, Flash and Fire points, Cloud and Pour points, calorie value, carbon residue, boiling point, Hydrocarbon test, UV spectroscopy.

\section{$5.1 \mathrm{pH}$ value:}

Result of $\mathrm{pH}$ value of Biooils are neutral which indicates its suitability of Biofuel, Samples of diesel also in neutral. High temperature over a period of time has degraded and reduced its quality.

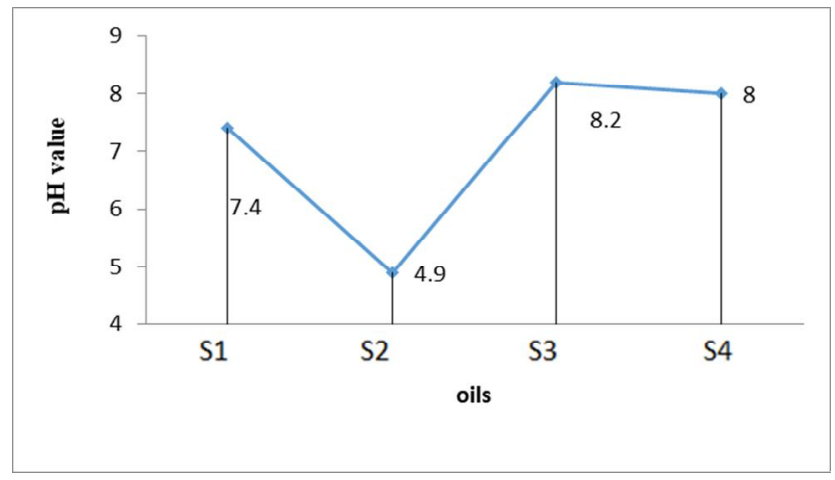

Fig 1: $\mathrm{pH}$ value

By analyzing the results for $\mathrm{pH}$ value of all samples, $\mathrm{S} 3$ shows better results compared to S1 and S2, which is nearer to $\mathrm{S} 4$.

\subsection{Flash point:}

Minimum for Bio-oil, are higher than that of diesel fuel. Higher flash point can also reduce auto ignition. During transportation it reduces fire hazards at high temperatures. Therefore, it is measure of flammability of fuels and also important safety criterion.

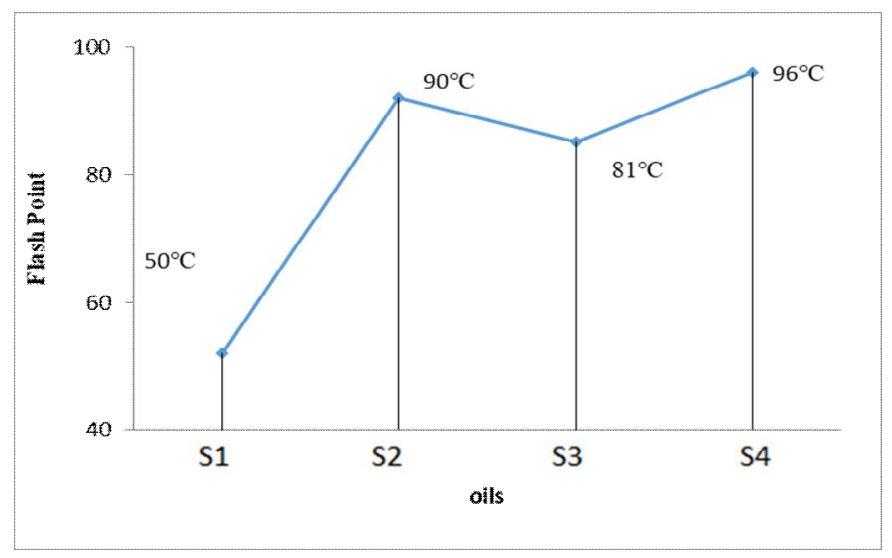

Fig 2: Flash point

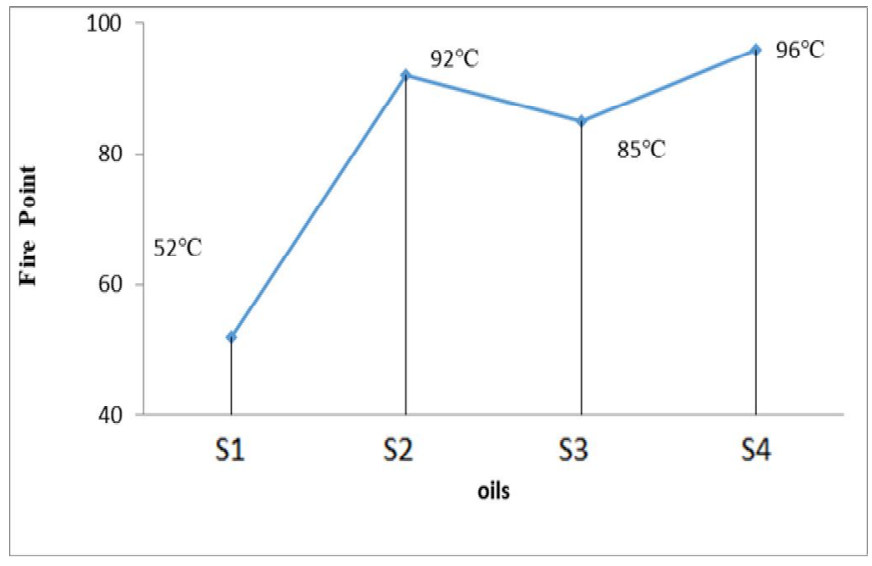

Fig 3: Fire point 
K.M.V Ravi Teja et al., International Journal of Emerging Trends in Engineering Research, 8(10), October 2020, 7062 - 7068

By analyzing the results for flash and fire point of all samples, S2 shows better results compared to $\mathrm{S} 1$ and $\mathrm{S} 2$, which is nearer to $\mathrm{S} 4$

\subsection{Redwood viscosity:}

One of the important property of Bio-oil is viscosity, mainly it effects on operation of fuel injection equipment. Viscosity is the primary cause of interest in relation and settling rates of contaminants.

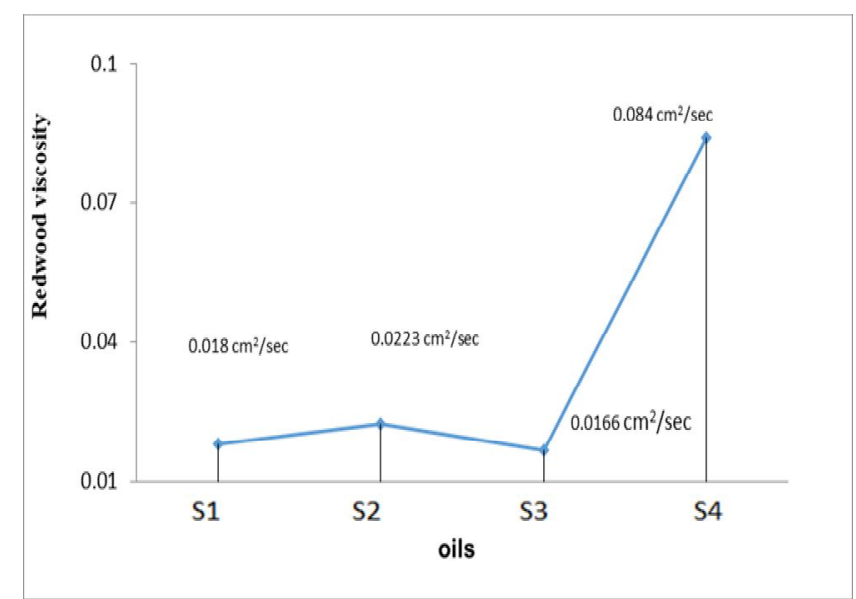

Fig 4: Viscosity

By analyzing the results for viscosity of all samples, $\mathrm{S} 2$ shows better results compared to $\mathrm{S} 1$ and $\mathrm{S} 3$, which is nearer to $\mathrm{S} 4$.

\subsection{Calorific value:}

Enthalpy released after completion of combustion at constant pressure or volume. Fuels having higher calorific values it will helps in lower flow rate. Calorific value increases after transesterification, due to glycerol removed from oil.

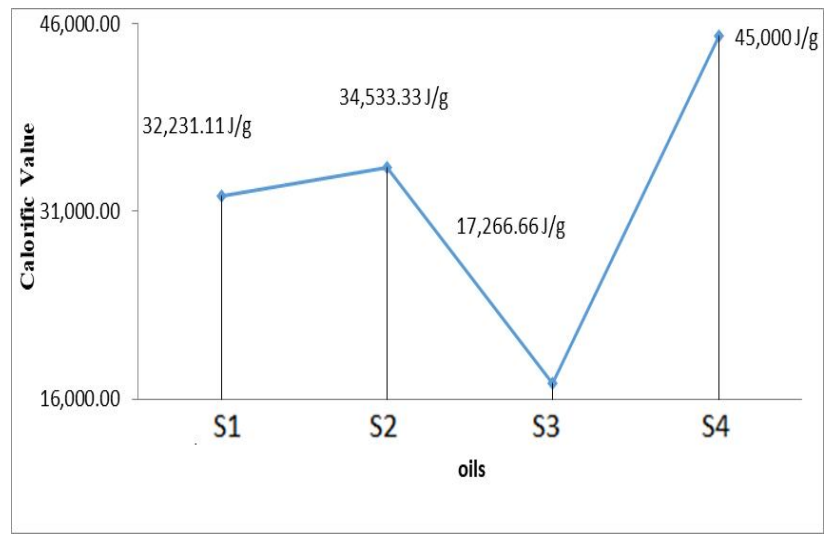

Fig 5: Calorific value

By analyzing the results for viscosity of all samples, $\mathrm{S} 2$ shows better results compared to $\mathrm{S} 1$ and $\mathrm{S} 3$, which is nearer to $\mathrm{S} 4$.
5.5 Carbon residue:

After burning of sample of Bio-oil, subjected to thermal decomposition. Therefore the test gives indication of cooking tendency. Excessive level of carbon residue is inadequate purification and also organic impurities.

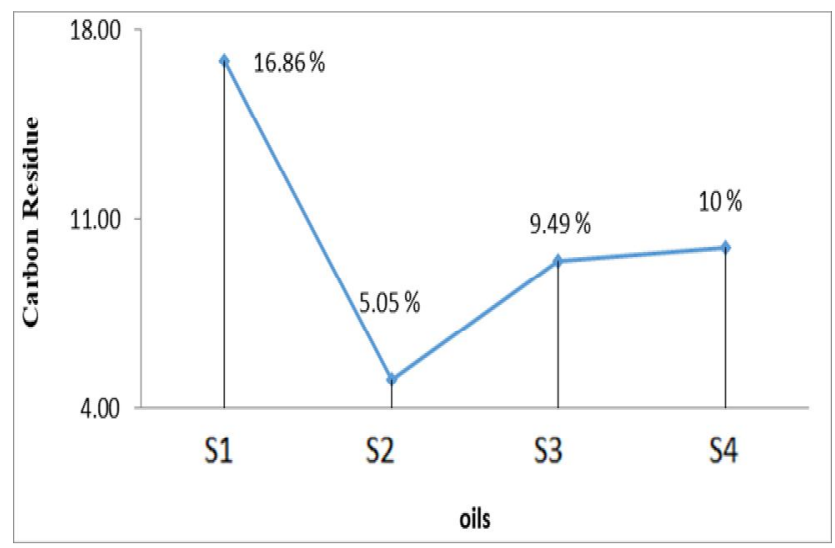

Fig 6: Carbon residue

By analyzing the results for viscosity of all samples, $\mathrm{S} 3$ shows better results compared to $\mathrm{S} 1$ and $\mathrm{S} 2$, which is nearer to $\mathrm{S} 4$.

5.6 Cloud and Pour point:

Behavior of oil is an important criteria, frozen oil will cause blockage of filters and starve the engine. Cloud and pour points will cause cold soak filter plugging at above $0 \square$ in cold temperature behavior of fuels.

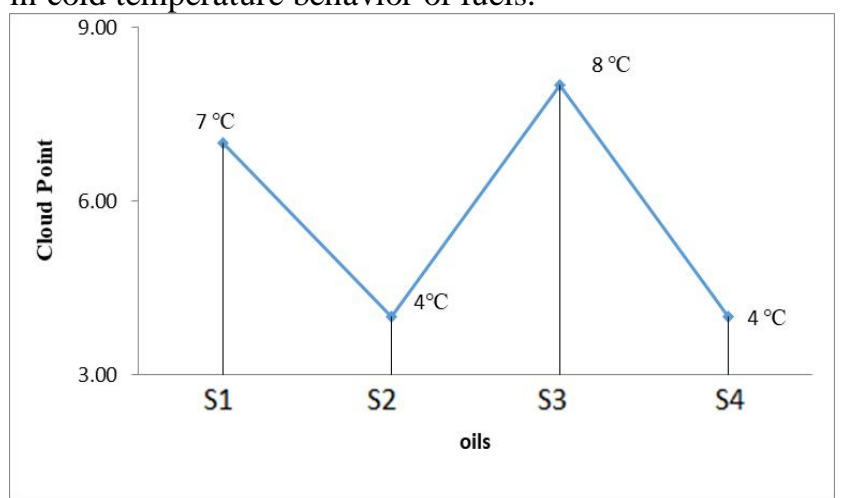

Fig 7: Cloud point

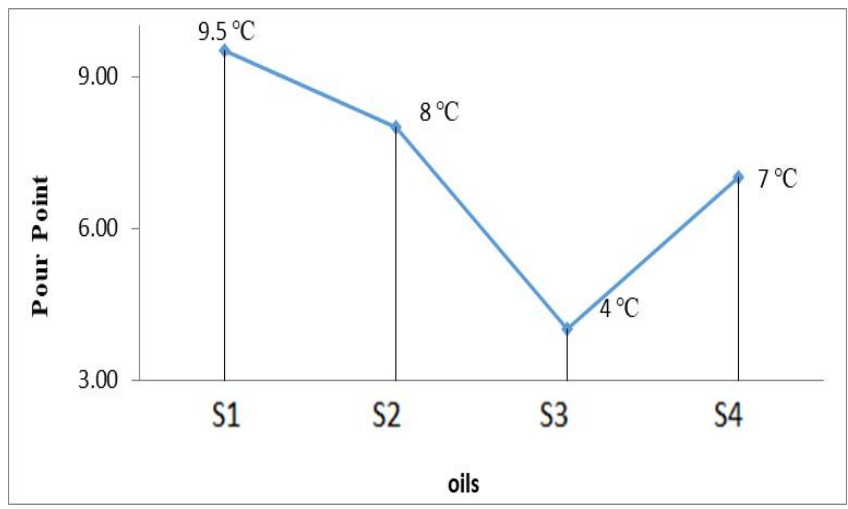

Fig 8: Pour point 
K.M.V Ravi Teja et al., International Journal of Emerging Trends in Engineering Research, 8(10), October 2020, 7062 - 7068

By analyzing the results for Cloud point of all samples, $\mathrm{S} 3$ shows better results compared to S1 and S2, which is nearer to S4.

\subsection{Boiling point:}

Over a temperature range of Bio-oil, opposed to having a single point for a pure compound. The range of boiling covers the temperature interval from the initial boiling. The boiling range for oil may exceed $500 \square$.

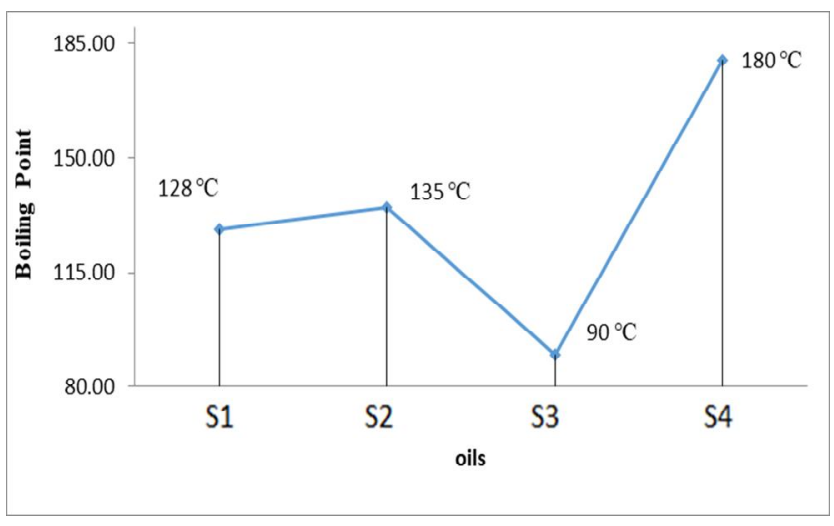

Fig 9: Boiling point

By analyzing the results for viscosity of all samples, S2 shows better results compared to $\mathrm{S} 1$ and $\mathrm{S} 3$, which is nearer to S4.

5.8 Flame test:

$2 \mathrm{ml}$ quantity of biooil in a clean and dry spatula is introduced into the flame. When the substance burns with smoky flame subjected to aromatic compound, substance burns with non smoky flame subjected to aliphatic compound. Detect the presence of certain elements, primarily metal ions, based on each element's characteristic emission spectrum.

\begin{tabular}{|c|c|c|c|}
\hline S1 & S2 & S3 & S4 \\
\hline Substance & Substance & Substance & Substance \\
burns with & burns with & burns with & burns with \\
smoky & smoky & smoky & smoky \\
flame & flame & flame & flame \\
which & which & which & which \\
indicates & indicates & indicates & indicates \\
aromatic & aromatic & aromatic & aromatic \\
compound & compound & compound & compound \\
\hline
\end{tabular}

Table no.3: Flame test results

\subsection{Pirate test of hydrocarbons:}

Pinch of picric acid with $5 \mathrm{ml}$ of biooil is taken and shaken gently, in a hot condition a yellow precipitate observed which indicates presence of naphthalene, when red precipitate is observed which indicates presence of Anthracene.

\begin{tabular}{|l|l|l|l|}
\hline \multicolumn{1}{|c|}{ S1 } & \multicolumn{1}{c|}{ S2 } & \multicolumn{1}{c|}{ S3 } & \multicolumn{1}{c|}{ S4 } \\
\hline Observed & Observed & Observed & Observed \\
Red Color & Red Color & Red Color & Red Color \\
so, & so, & so, & so, \\
Presence of & Presence of & Presence of & Presence of \\
Anthracen & Anthracen & Anthracen & Anthracen \\
e & $\mathrm{e}$ & $\mathrm{e}$ & $\mathrm{e}$ \\
& & & \\
\hline
\end{tabular}

Table no.4: Pirate test results

\subsection{Aluminum chloride test of hydrocarbon:}

$5 \mathrm{ml}$ of biooil dissolve in chloroform and add anhydrous aluminum chloride. Alcl3 crystals attain yellow color but turns to deep orange within few minutes which indicates presence of benzene, when chloroform layer is colourlessAlCl3 crystals turn to orange colour which indicates presence of toluene, when choloroform layer is yellow in colour green colour occurs immediately which on standing turns toluene colour pale greenish yellow colour indicates presence of naphthalene, when choloroform layer is colourless which indicates presence of Anthracene.

\begin{tabular}{|l|l|l|l|}
\hline \multicolumn{1}{|c|}{ S1 } & \multicolumn{1}{c|}{ S2 } & \multicolumn{1}{c|}{ S3 } & \multicolumn{1}{c|}{ S4 } \\
\hline Observed & Observed & Observed & Observed \\
Colorless so & Colorless so & Colorless so & Colorless so \\
presence of & presence of & presence of & presence of \\
Anthracene & Anthracene & Anthracene & Anthracene \\
\hline
\end{tabular}

Table no.5: Aluminum chloride test results

\subsection{UV spectroscopy:}

UV absorbance feature obtained with Bio-oil of undefined path length onto a wall, Bio-oil spectra exhibits a number of well-resolved peaks. UV/VIS spectrometer, with a graphical output and a non-linear wavelength scale.

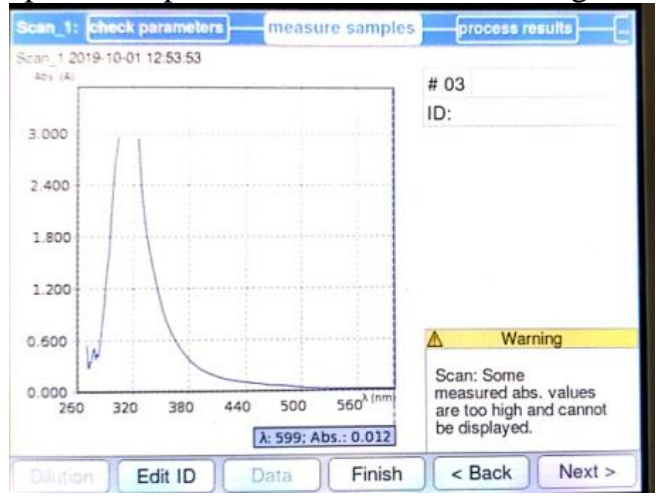




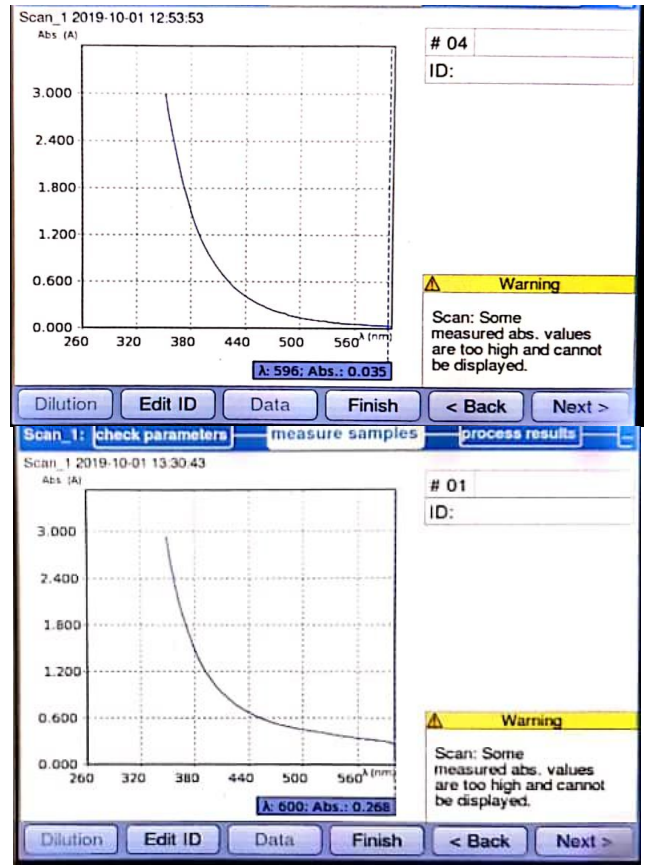

Fig 10: UV spectroscopy

\section{CONCLUSION}

Based on the experimental results,most of the properties of the biooils are within the limits for biodiesel and can be used as alternative fuel for diesel engines.

\section{REFERENCES}

1. Ramadhas, A.S., Jayaraj, S. and Muraleedharan, C. Characterization and the effects of using rubber seed oil as fuel in the compression ignition engines. Renewable Energy. 2005;30(5):795-803.

2. VisnusarathyDhakshinamurthy (Gobichettipalayam, Bala Murugan R, (2014). Experimental Investigation of Performance and Emission Characteristics of Syzygium cumini Seed Oil Methyl Ester (JOME) in Single Cylinder Compression Ignition Engine. International Journal of Science, Engineering and Technology Research (IJSETR), Volume 3: 3203-3212).

3. H.C. Ong, H.H. Masjuki, T.M.I. Mahlia, A.S. Silitonga, W.T. Chong \& Talal Yusaf, "Engine performance and emissions using Jatropha curcas, Ceiba pentandra and Calophyllum inophyllum biodiesel in a CI diesel engine", Energy, 69 (2014) 427-445.

4. Nidal H. Abu-Hamdeh and Khaled A. Alnefaie , A Comparative Study of Almond Biodiesel-Diesel Blends for Diesel Engine in Terms of Performance and Emissions, BioMed Research International, Volume 2015, Article ID 529808, 8 pages

5. .L.C. Meher, D. VidyaSagar, S.N. Naik, Technical aspects of biodiesel production by Transesterification-a review, Renewable and Sustainable Energy Reviews, Volume 10, 2006, Pages 248-268.
6. Garpen, J.V., Biodiesel processing and production, Fuel Processing Technology, Vol. 86, 2005, Pages 1097-1107.[6]

7. Ebewere RO, Iyayi AF, Hymore FK. Considerations of the extraction process and potential technical applications of Nigerian rubber seed oil. Int. J. of the physical Sci.2010;(6):826-831.

8. Goodrum, JW, Kilgo MD. Peanut extraction using compressed carbon dioxide. Eng. In. Agric. 1986; 8:265-271.

9. Sayyar S, Abidin SS, Yunus R, Muhammed A. Extraction of oil from jatropha seeds- Optimization and kinematics. Am. J. App. Sci. 2008;6(7):1390-1395.

10. E. I. Bello, A. O. Akinola, F. Otu and T. J. Owoyemi. Fuel and Physiochemical Properties of Anacardium occidentale (Anarcardium 1 occidentale) Nut Oil, Its Biodiesel and Blends with Diesel. British Journal of Applied Science \& Technology 3(4): 1055-1069, 2013.

11. A. EnginOzcelik, Hasan Aydog an, Mustafa Acarog lu , Determining the performance, emission and combustion properties of camelina biodiesel blends,Energy conversion and management, Energy Conversion and Management 96 (2015) 47-57.

12. Vlada B. Veljkovic ,Ivana B. Bankovic-Ilic, Olivera S. Stamenkovic: Purification of crude biodiesel obtained by heterogeneouslycatalyzedtransesterification, Renewable and Sustainable Energy Reviews, Volume 49, 2015, Pages 500-516.

13. C. Syed Aalam, C.G. Saravanan: Biodiesel Production Techniques: A Review. International Journal for Research in Applied Science and Engineering Technology, Volume 3, 2015, Pages 41-45.

14. C. Syed Aalam, C.G. Saravanan. Biodiesel Production from Mahua oil via Catalytic transesterification method. International Journal of ChemTech Research.Vol.8 (4), pp 1706-1709, 2015.

15. A.M. Ashraful, H.H. Masjuki, M.A. Kalam, I.M. Rizwanul Fattah, S. Imtenan, S.A. Shahir, H.M. Mobarak. Production and comparison of fuel properties, engine performance, and emission characteristics of biodiesel from various non-edible vegetable oils: A review. Energy Conversion and Management, Volume 80, 2014, Pages 202-228.

16. GauravDwivedi, M.P. Sharma, Potential and limitation of straight vegetable oils as engine fuel - An Indian perspective, Renewable and Sustainable Energy Reviews, Volume 33, 2014, Pages 316-322.

17. Bacon, D.Brear M F, 1 .D, Mancreff and Walker K L " The Use of Vegetable Oils inStraight and Modified as Diesel Engine Fuels" Beyond the Energy Crisis, Vol-111,ergamon Press, Oxford, England, 1981, pp 1525- 1533.

18. Hyunok Lee, " Ethanol's Evolving Role in the U.S, Automobile Fuel Market,Industrial uses of Agricultural Materials, U. S, Department of Agrjcultm, office ofEnergy, June 1993. 
19. SuTRA" Draft National Bio-Fuel Policy" prepared for the All India Seminar on theNational Policy on Nonedible oils as Bio-fuels, organized by Indian Institute of Science in Bangalore from 1\&2 Feb.2003.

20. Barsic N J and Humke A L, "Performance and Emission Characteristics of a Naturally,Aspirated Diesel Engine with Vegetable Oil Fuels" SAE paper No. 810262.

21. K.Venkateswarlu, Y.V Hanumantha Rao, K.Sridhar.,R.B.VMurali., Isobutanol and Ethyl Hexyl Nitrate(EHN) as additives for performance and emission improvement of Diesel-Biodiesel fuelled Diesel Engine. Proceedings of National conference on "Advances in Mechanical Engineering" (AIM-2012), Vasavi college of Engineering, Hyderabad, October 2012.

22. Kota Sridhar, R.B.V.Murali, Sk.MohamadYounis, K.MohanLakshmi.'Computerized Simulation of Spark Ignition Internal Combustion Engine”. IOSR Journal of Mechanical and Civil Engineering (IOSR-JMCE) e-ISSN: 2278-1684 Volume X, Issue X (Jan. - Feb. 2013), PP 01-00

23. Kota Sridhar, G.Durga Prasad, R.B.V.Murali, K.MohanaLakshmi"Numerical Flow simulation of spark ignition internal combustion Engine using Hexane as Fuel" .IJESR April 2013/ Vol 3/Issue 4/132-143 e-ISSN2277-2685,p-2320-9763.

24. R.B.V.Murali, Y.V.Hanumantha Rao, K.Venkateswarlu,V.Ranjith Kumar, Performance and Emissions Evaluation of Diesel Engine with Pre-Heated Bio Diesel, Academic Projects, International Journal of Engineering Science Invention ISSN (Online): 2319 - 6734, ISSN (Print): 2319 - 6726 , Volume 2 Issue 6 ,June. 2013 ,PP.63-71.

25. Rao, YVH; Voleti, RS; Hariharan, VS; Reddy, PN; Raju, AVSR," PERFORMANCE AND EMISSION CHARACTERISTICS OF DIESEL ENGINE WITH METHYL ESTER JATROPHA OIL AND ITS BLENDS", ENERGY \& ENVIRONMENT,Dec-Jan 2009

26. Arunkumar, M; Kannan, M; Murali, G,' Experimental studies on engine performance and emission characteristics using castor biodiesel as fuel in CI engine", RENEWABLE ENERGY, Feb 2019.

27. Yarrapathruni, VHR; Voleti, RS; Pereddy, NR; Alluru, VSR," JATROPHA OIL METHYL ESTER AND ITS BLENDS USED AS AN ALTERNATIVE FUEL IN DIESEL ENGINE”, THERMAL SCIENCE, 2009.

28. Sarma, Pullela K.; Konijeti, Ramakrishna; Subramanyam, Tunuguntla; Prasad, Lankapalli S. V.; Korada, Viswanatha S.; Srinivas, Vadapalli; Vedula, Dharma R.; Prasad, Veerapanen S. R. K.,Fouling and its effect on the thermal performance of heat exchanger tubes,INTERNATIONAL JOURNAL OF HEAT AND TECHNOLOGYVolume-35,2017,Pg-509-519.

29. Rajanish, Chava Y. P. D. Phani; Rao, B. Nageswara,On the Radiative Heat Transfer in a Viscoelastic
Boundary Layer Flow Over a Stretching Sheet,JOURNAL OF HEAT TRANSFERTRANSACTIONS OF THE ASMEVolume-139,2017.

30. Vedavathi, N.; Dharmaiah, G.; Balamurugan, K. S.; Prakash, J.,HEAT TRANSFER ON MHD NANOFLUID FLOW OVER A SEMI INFINITE FLAT PLATE EMBEDDED IN A POROUS MEDIUM WITH RADIATION ABSORPTION, HEAT SOURCE AND DIFFUSION THERMO EFFECT,FRONTIERS IN HEAT AND MASS TRANSFERVolume-9,2017.

31. Dutta, Oruganti Yaga; Rao, B. Nageswara,Investigations on the performance of chevron type plate heat exchangers, HEAT AND MASS TRANSFER, Volume-54,2018,Pg-227-239.

32. Gudala, Manojkumar; Banerjee, Shirsendu; Kumar, Ravindra; Rao, T. Rama Mohan; Mandal, Ajay; Naiya, Tarun Kumar, Experimental Investigation on Hydrodynamics of Two-Phase Crude Oil Flow in Horizontal Pipe With Novel Surfactant,JOURNAL OF FLUIDS ENGINEERING-TRANSACTIONS OF THE ASMEVolume-140,2018

33. Arunkumar, M.; Kannan, M.; Murali, G.,Experimental studies on engine performance and emission characteristics using castor biodiesel as fuel in CI engine, RENEWABLE ENERGYVolume-131,2019,Pg-737-744.

34. Returi, Madhuri Charulatha; Konijeti, Ramakrishna; Dasore, Abhishek,Heat transfer enhancement using hybrid nanofluids in spiral plate heat exchangers, HEATTRANSFER-ASIAN RESEARCHVolume-48,2019,Pg-3128-3143. 